medical and nursing staff exist to assist them in doing what needs to be done while not usurping the parents' role."

\footnotetext{
${ }^{1}$ Richards, M P M, and Roberton, N R C, in Separation and Special Care Baby Units (Clinics in Developmental Medicine, No 68), ed F S W Brimblecombe, M P M Richards, and N R C Roberton, chap 7. Spastics International Medical Publications, London and Philadelphia, Heinemann and Lippincott, 1978.

${ }^{2}$ Committee on Child Health Services (chairman Professor S D M Court), Fit for the Future. London, HMSO, 1976.

${ }^{3}$ Brimblecombe, F S W, et al, in Separation and Special Care Baby Units (Clinics in Developmental Medicine, No 68), eds F S W Brimblecombe, M P M Richards, and N R C Roberton, chap 6. Spastics International Medical Publications. London and Philadelphia, Heinemann and Lippincott, 1978.

4 Roberton, N R C, Archives of Disease in Childhood, 1977, 52, 819

5 Alberman, E, et al, British Medical fournal, 1977, 2, 1045.

${ }^{6}$ Kitchen, W H, et al, Developmental Medicine and Child Neurology, 1978, 20, 605 .

7 Stewart, A L, and Reynolds, E O R, Pediatrics, 1974, 54, 724.

8 Davies, P A, and Stewart, A L, British Medical Bulletin, 1975, 31, 85.

9 Separation and Special Care Baby Units (Clinics in Developmental Medicine, No 68), eds F S W Brimblecombe, M P M Richards, and N R C Roberton. Spastics International Medical Publications. London and Philadelphia, Heinemann and Lippincott, 1978.

10 Klaus, $\mathrm{M} \mathrm{H}$, and Kennell, $\mathrm{J} \mathrm{H}$, in Recent Advances in Paediatrics, no 5 , ed D Hull. Edinburgh, Churchill Livingstone, 1976.
}

\section{Epilepsy and learning}

At least 60000 schoolchildren in Britain have epilepsy ${ }^{1}$ and most of them are educated in ordinary schools. Learning and behaviour problems are more common in epileptic than in normal children, and a recent study from Oxford ${ }^{2}$ attempted to identify the children at greatest risk of problems at school. Boys but not girls seemed predisposed to a range of behavioural complications, but whether this was a biological phenomenon or socially determined remained uncertain. A persistent left temporal spike discharge was associated with backwardness in reading, inattentiveness, emotional dependence, and overactivity.

The possibility that the type and site of epileptic discharges are related to a particular behaviour disorder in children has only rarely been considered before. Nuffield ${ }^{3}$ noted that children with 3-per-second spike-and-wave discharges were shy, retiring, or neurotic; in contrast, those with temporal lobe spike discharges were aggressive or antisocial. In those studies, however, neither the side of the lesion nor sex was included in the analysis. Flor-Henry ${ }^{4}$ described severe forms of behaviour disturbance in adults with left temporal lobe lesions. McIntyre et $a l^{5}$ claimed that young adult patients with right temporal spike discharges were more impulsive than those with left temporal spike discharges; while Lishman ${ }^{6}$ suggested that left temporal lobe dysfunction in adults was particularly associated with psychiatric complications.

For many children the drugs used in treatment cause more school problems than the fits. In the Oxford study treatment with phenytoin was associated with poor reading, confirming studies from the same unit that had shown the harmful effects of the drug on intelligence and behaviour. ' Unfortunately, the drug concentrations in the blood were not measured routinely and there was no attempt to monitor compliance in any other way. The high incidence of behaviour disorders, particularly aggressiveness, in young children receiving phenobarbitone has persuaded many paediatricians to avoid this drug in epilepsy. ${ }^{8}$ Teachers in ordinary schools have very little medical knowledge, and disturbed behaviour or poor progress may be considered an inevitable effect of epilepsy or of effective drug treatment. The dozing child at the back of the class in the afternoon session may be a welcome respite to the teacher who has been contending with an aggressive rebel all morning. School medical officers and educational psychologists may assume that the child is having optimal care simply because he has appointments for an outpatient clinic-yet these visits may amount to nothing more than a cheerful greeting from the new paediatric house physician and a repeat prescription.

Many children with epilepsy will grow up to become adults with epilepsy, and their possible occupations will be restricted. They are more likely to be employable if they are literate. It is therefore particularly important that epileptic children should learn well during their early years at school. Optimal management is not simply preventing fits. Most district hospitals can now routinely estimate blood concentrations of most anticonvulsants, and a child's drug concentrations should be checked if there are behaviour or learning problems. Many children are well controlled with phenytoin without side effects, and they should continue to receive it; but if there are substantial side effects sodium valproate should usually be substituted. Sodium valproate is the first choice in new patients, though the evidence of long-term effects on behaviour and educational progress is scanty. The common side effects are drowsiness, nausea, anorexia, or excessive appetite; but these are often temporary. Excessively high doses may cause thrombocytopenia.

School medical officers of the new style ${ }^{9}$ have a responsibility for particular schools, and their close contact with teachers should give them the opportunity to hear about these learning problems. Children with epilepsy attending hospitals are likely to visit a general paediatric clinic rather than a neurological clinic: the message from Oxford is that epilepsy is not just fits.

${ }^{1}$ Gulliford, R, Special Educational Needs. London, Routledge and Kegan Paul, 1971.

- Stores, G, Developmental Medicine and Child Neurology, 1978, 20, 502

3 Nuffield, E J A, Fournal of Mental Science, 1961, 107, 438.

4 Flor-Henry, P, Epilepsia. 1972, 13, 773.

${ }^{5}$ McIntyre, M, Pritchard, P B, and Lombroso, C T, Epilepsia, 1976, 17, 377

${ }^{6}$ Lishman, W A, British fournal of Psychiatry, 1968, 114, 373.

7 Stores, G, Developmental Medicine and Child Neurology, 1975, 17, 647.

8 Bower, B D, in Paediatric Therapeutics, ed H B Valman, p 51. Oxford, Blackwell Scientific, 1979.

${ }^{9}$ Department of Health and Social Security, Health Services Development Court Report on Child Health Services, 1978, HC(78)5. London, DHSS, 1978. 